\title{
Communication
}

\section{A Liberal Undergraduate Education for Engineers}

\author{
C. Judson King
}

Center for Studies in Higher Education and Department of Chemical and Biomolecular Engineering, University of California, Berkeley, CA 94720-1462, USA; cjking@berkeley.edu

Received: 12 June 2020; Accepted: 10 August 2020; Published: 12 August 2020

\begin{abstract}
The complex dimensions of many issues faced by engineers require that they understand social and humanistic matters along with the technical, and communicate effectively and synergistically with persons having all sorts of backgrounds. This is especially true for matters of sustainability and energy supply. Engineering should therefore be built upon the foundation of a broad and liberal undergraduate education, with the professional degree being moved to the graduate level, as is the case for the other major professions. Another benefit of moving the degree level can be to delay the point of commitment to an engineering major from before college to the latter part of the undergraduate program, a move which can bring in new enrollees and increase diversity. The move of the professional engineering degree to the graduate level has already happened for a number of European countries as an outgrowth of the Bologna Process. There are incremental changes that can be made so that this transition can be undertaken by evolution as opposed to revolution.
\end{abstract}

Keywords: engineering education; professional degree; Bologna Process; master's programs; delayed choice of major

\section{Introduction}

Among the major professions, engineering is the only one that traditionally has had the professional degree at the undergraduate level in most parts of the world. Here, I define the professional degree as that degree which enables recipients to practice the profession generally. The constraint of fitting it all within a bachelor's-degree program has resulted in crowded curricula with very little breadth of content beyond the technical. That fact is sometimes a badge of pride for engineering students and recent graduates, as is evidenced by emails from our local MIT alumni club describing their "Talk Nerdy to $\mathrm{Me}^{\prime \prime}$ social events and the existence of the Cal NERDs as a social focus for engineering students here at Berkeley. But given the large social dimensions and complexity of many issues in which engineers are now involved, that narrowness of education is in fact a major weakness. Engineers need to understand social and humanistic matters along with the technical, and they must be able to communicate effectively and synergistically with persons having all sorts of backgrounds. One need look no further than the needs of sustainability itself. Among the many current issues that integrate the technical intimately with the non-technical, some of the most significant are global warming; water, energy, and food supplies; the complexities, unknowns, and anxieties surrounding the 2020 coronavirus pandemic; and the many ways in which modern information technology affects our lives. Further afield, about one-third of engineering-degree holders are not initially employed in areas that are close to their professional training, a figure that grows to over $50 \%$ as careers progress [1]. These graduates should be served well educationally, too.

Some envision sustainability as a new academic discipline or as an area best served by people who themselves are interdisciplinary. But sustainability is really multi- or trans-disciplinary in the sense that it requires that people from the different relevant disciplines work closely together, with each of them being fully versed in their particular discipline. The field is best served by multidisciplinary 
research centers and collaborations among researchers from different disciplines rather than by individuals or even teams from within a single discipline. Hence, the need is for people who know their own discipline thoroughly and yet understand enough about other disciplines and have strong communication and intellectual skills that enable them to work closely and effectively with persons from those other disciplines.

\section{Broader Undergraduate Education with Movement of the Engineering Professional Degree to the Graduate Level}

The abilities of engineers to understand and work synergistically with persons from a variety of disciplines are best developed through a broad and liberal undergraduate college education. (The meaning of liberal here is in the educational context, not in the political sense of the word.) In the United States, for the past hundred years, professional education for medicine has operated at the postgraduate level, built upon the base of a broad and flexible undergraduate education. "Pre-med" undergraduate students should take some generally agreed upon courses in sciences and other areas, but their undergraduate majors can be in almost any field. The broad knowledge from such an undergraduate education complements medical skills in practice and results in more mature and aware students in medical school. The same structure and motivating factors pertain for law and most other professions, such as architecture, public health, and journalism. Some medically related professions, notably pharmacy, nursing practice, physical therapy, and audiology, have recently transitioned, or are transitioning, upward to the doctorate as the professional degree. In addition to breadth, other driving forces are greater professional content and status.

The idea that engineers should have a broad-based undergraduate education with the professional degree moved to the postgraduate level is not new. It was put forward in the Goals of Engineering Education report [2] of the American Society for Engineering Education (ASEE) fifty-five years ago. The Educating the Engineer of 2020 report of the U.S. National Academy of Engineering in 2005 recommended that "the B.S. degree should be considered as a preengineering or 'engineer in training' degree and that engineering programs should be accredited at both the B.S. and M.S. levels, so that the M.S. degree can be recognized as the engineering 'professional' degree" [3]. Movement of the professional degree to the graduate level was the central theme of the 5XME Workshop on mechanical engineering education in 2009 [4]. Augustine [5], Duderstadt [6,7], Wulf [8], Scherer and Smith [9], Pister [10], the author [11,12], and others have written promoting the concept. However, all along there has been substantial resistance and/or non-interest in these recommendations from most engineering faculty, deans, and professional societies; see, e.g., the analysis by Grose [13]. On the whole, the engineering community in the United States and much of the rest of the world remains firmly in the structure of an undergraduate professional degree. Licensing, which certifies a licensee's capabilities within the professional field, has, on the other hand, moved in various parts of the world to requirements of the master's and/or professional practice. However, licensing is not a common requirement for engineering practice outside the more public fields such as civil and sanitary engineering. Undergraduate co-op programs can also provide relevant experience.

As is evidenced by the references already cited, in the United States the strongest recommendations for breadth and for movement of the professional degree to the graduate level tend to come from engineers who have been in leadership positions where they have been immersed in the big picture, such as university presidents and provosts, corporate CEOs, and heads of national organizations. The resistance from engineering faculty members often stems from more appreciation for their own discipline as opposed to other disciplines, and recognition that the change in degree structure would be a very large undertaking and therefore an added burden. The resistance from deans can also relate to considerations of budget and enrollment credit within universities. Added education for engineers brings costs for students and universities. Undergraduate enrollments in engineering courses would decrease because fewer of those courses would be taken by undergraduate engineering students. But graduate enrollments would go up, and in many university systems graduate enrollments count 
more for budget than do undergraduate enrollments. In addition, there are worries that the overall percentage of university students achieving the engineering professional degree could decrease because students could be discouraged by the added time consumed by education beyond the bachelor's level. But it is also true that the decision point for a student to choose engineering as a major and/or profession could be delayed from before college, as things are now, to the junior or even senior undergraduate year. There are students who are reluctant to commit to engineering and especially the narrowness of an engineering education before they have had a taste of what college is like. Those students could make much more informed choices if the selection of engineering as a major is deferred until the latter half of their undergraduate studies. Research has shown that women have more of a preference for prosocial responsibilities than men as they choose majors [14], and that they go more into people-oriented engineering disciplines [15]. Hence, they can shy away from engineering because of reluctance to give up a liberal undergraduate education. The broader undergraduate education and delay in the decision point could substantially increase both the numbers and the gender balance and other measures of diversity of students entering the field. It would thereby bring into engineering students who would not have chosen it otherwise.

Even though there are corporate leaders who recognize the value of the broader education for engineers in terms of worth to the company and opportunities for career advancement, supervisors and industrial recruiters tend to think of engineering hiring needs more in terms of initial job functions. Industrial members of professional societies are most numerous from the lower levels of industry, and thus professional engineering societies tend not to reflect the outlooks of corporate leaders well.

The other constituency involved is, of course, the students themselves, and it is they who would benefit most from a movement of the professional degree to the graduate level, in terms of having both more career-advancement opportunities and fuller lives. Yet they are usually not represented at all in deliberations on the possibility of moving the professional degree. Recent surveys [16] of engineering students in 18 U.S. public universities have consistently shown that most of them seek a broader undergraduate education. These desires are probably not unique either to Berkeley or to chemical engineering among engineering disciplines.

\section{The Bologna Process}

Movement of the engineering professional degree to the graduate level has now happened to a substantial extent in Europe over the past two decades as a side-product of the Bologna Process [17], which was started as a collaborative effort by national governments and ministers of Europe in 1999 and now involves 48 different countries. The Bologna Process was undertaken to gain a more common structure of university degrees among countries so as "to facilitate student and staff mobility, to make higher education more inclusive and accessible, and to make higher education in Europe more attractive and competitive worldwide" [18]. The result was adoption of a common format of a three- to four-year first-cycle degree followed by a one- to two-year second-cycle degree and then a third-cycle degree that corresponds to the doctorate. Since secondary education in much of Europe typically involves one more year than in the United States, the first- and second-cycle degrees correspond closely to the U.S. bachelor's and master's degrees and were intentionally designed to be that way. The changes in overall degree structure have, in turn, necessitated consideration of the degree structures for engineering [19], with the result being that many of the countries involved have now placed the professional engineering degree at the second-cycle, or master's, level [20-22]. This result was facilitated by the fact that some countries, such as France, already had longer programs toward their professional degree in engineering.

The Bologna Process has generated some interest in some other parts of the world, such as Australia, China, and Japan, but it has not resulted in much change for engineering education there. One exception, not stemming directly from the Bologna Process, is that the University of Melbourne in Australia has had the professional engineering degree at the master's level since the restructuring associated with the introduction of the Melbourne Model [23] and many fewer but broader undergraduate majors in 2008. It has not been necessary for the United States and other 
countries with degree structures similar to that in the U.S. to adapt in response to the Bologna Process, and it has thereby attracted much less attention in those countries.

\section{Moving Ahead}

The results of the placement of the professional degree at the master's level in many European countries and the University of Melbourne are well worth following, since they provide a frame of reference with regard to the benefits which that change could bring about in other countries. It is also important that leaders, including recognized intellectual leaders, continue to speak out concerning the need for movement of the professional degree in engineering to the graduate level, if they believe in that objective. It will help if leaders of industry who support the idea communicate that fact to their engineering employees and thereby more effectively to professional societies. Other entities in the United States whose support for the change would be important include the National Academy of Engineering, the Association of American Universities, the President's Science Advisory Committee, and the National Science Board, and the same would apply to similar bodies in other countries. Major private foundations and the National Science Foundation can also be influential, particularly through financial support for initiatives.

There was a time in the not-so-distant past when engineering education underwent a wrenching change of a different sort. That was in the aftermath of World War II when much more mathematics and science came into the engineering curriculum in the United States. The impetus stemmed from the ways in which the large technological advances of World War II had come about. Projects such as those for the atomic bomb and radar had been carried out largely by younger scientists rather than by engineers, even though the projects were heavily engineering in nature. The belief of many at the time was that engineers did not have the sort of education that would enable them to undertake entirely new science-based creative advances [24]. Engineering educators did respond, and much more math, science, and ways of using fundamental science came into the curriculum by degrees over about a few decades $[25,26]$. The change was facilitated by the fact that it could happen incrementally over time, rather than being a single, large change.

Although it can appear that wholesale change by revolution, rather than evolution, is required for changing the professional degree to the graduate level, there are some evolutionary steps that can be attractive and would be effective for that purpose. An entrepreneurial initiative for individual universities could be a graduate-level professional degree in engineering specifically designed for students who have taken relevant supporting courses in math and science but not an engineering degree at the undergraduate level. The undergraduate program would then be analogous to that for pre-medical students; in fact, it might even be much the same. The new graduate program would serve those students who had not wanted to limit the breadth of their education by majoring in engineering as undergraduates. As already noted, this should be effective for both diversification and bringing in students who would otherwise not have become engineers. Financial aid would be important for such a graduate professional-degree program. It should be possible to interest one or more major foundations or private funders of the worth of providing aid to such an innovative program. This would be a way of starting to place the professional degree for engineering at the graduate level without the trauma of a sudden transition in degree structures. With success, the practice could then spread. In the United States, accreditation of such a new graduate degree can readily be obtained, since ABET now allows an institution to obtain accreditation at multiple degree levels.

This graduate-level professional degree following a liberal undergraduate education can also be viewed as a logical evolution from the various approaches that currently seek to maximize the amount of liberal education in an engineering bachelor's degree. These include 3-2 programs that combine three years at a liberal-arts college with an ensuing two years at a university offering engineering bachelor's degrees, the one-year BE following the four-year AB at Dartmouth, and completion of the full distribution requirements of the undergraduate liberal-arts college which is required as part of a bachelor's degree in engineering at institutions such as Harvard, Yale, and Smith. It can also be 
regarded as an evolution from the five-year programs giving both bachelor's and master's degrees at institutions such as MIT and Cornell, with the master's becoming the professional degree rather than the bachelor's. The ABET requirements [27] for accreditation of master's degrees are consistent with these evolutionary steps in that the requirements for education beyond the accredited bachelor's degree deal primarily with the total educational content, rather than the amount of specific engineering content.

The issues associated with sustainability for our world are highly multidimensional and complex, involving contributions from many different academic disciplines for progress. Engineers have central roles for gaining sustainability, but in order to carry them out, engineers need much more breadth of education, which can best be gained by moving the professional degree to the graduate level and basing it upon a liberal undergraduate education.

Funding: This research received no external funding.

Conflicts of Interest: The author declares no conflict of interest.

\section{References and Note}

1. Grasso, D.; Helble, J.J. Holistic engineering and educational reform. In Holistic Engineering Education: Beyond Technology; Grasso, D., Burkins, M.B., Eds.; Springer: New York, NY, USA, 2010; p. 87.

2. Walker, E.A.; Pettit, J.M.; Hawkins, G.A. Final report: Goals of engineering education. Eng. Educ. 1968, 367-446. Available online: https://www.asee.org/documents/publications/reports/goals_of_engineering_ education.pdf (accessed on 8 June 2020).

3. National Academy of Engineering. Educating the Engineer of 2020: Adapting Engineering Education to the New Century; National Academies Press: Washington, DC, USA, 2005. [CrossRef]

4. Ulsoy, A.G.; Wang, K.-W. (Eds.) Implementing the Recommendations of the 5xME Workshop. 2009. Available online: http://www-personal.umich.edu/ \{\}ulsoy/pdf/Implementing_5xME_Report.pdf (accessed on 8 June 2020).

5. Augustine, N.R. Re-engineering engineering. ASEE PRISM 2009, 18, 46-47.

6. Duderstadt, J.J. Engineering for a changing world. In Holistic Engineering Education: Beyond Technology; Grasso, D., Burkins, M.B., Eds.; Springer: New York, NY, USA, 2010; pp. 17-35.

7. Duderstadt, J.J. Engineering for a Changing World; Millenium Project; University of Michigan: Ann Arbor, MI, USA, 2008; Available online: https://deepblue.lib.umich.edu/handle/2027.42/58617 (accessed on 8 June 2020).

8. Wulf, W.A. How shall we satisfy the long-term educational needs of engineers? Proc. IEEE 2000, 88, 593-596. [CrossRef]

9. Scherer, W.; Smith, M. Time to rethink professional training. ASEE PRISM 2018, 27, 60.

10. King, C.J.; Pister, K.S. How Best to Broaden Engineering Education? Eng. Stud. 2015, 7, 150-152. [CrossRef]

11. King, C.J. Let engineers go to college. Issues Sci. Tech. 2006, 22, 25-28. Available online: https://issues.org/p king/ (accessed on 8 June 2020). [CrossRef]

12. King, C.J. Restructuring engineering education: Why, how and when? J. Eng. Educ. 2012, 101,1-5. [CrossRef]

13. Grose, T.K. Steeper ascent: Should a master's be the minimum for engineers? ASEE-PRISM 2012, 21, $24-27,29$.

14. Shi, Y. The puzzle of missing female engineers: Academic preparation, ability beliefs, and preferences. Econ. Educ. Rev. 2018, 64, 129-143. [CrossRef]

15. Yoder, B.L. Engineering by the numbers. Am. Soc. Eng. Educ. 2016. Available online: https://www.asee.org/ papers-and-publications/publications/college-profiles/15EngineeringbytheNumbersPart1.pdf (accessed on 20 July 2020).

16. Student Experience in the Research University, Center for Studies in Higher Education, University of California, Berkeley. Available online: https://cshe.berkeley.edu/seru (accessed on 8 June 2020).

17. Bologna Process. Wikipedia. Posted 5 June 2020. Available online: https://en.wikipedia.org/wiki/Bologna Process (accessed on 8 June 2020).

18. European Commission. The Bologna Process and the European Higher Education Area. Available online: https://ec.europa.eu/education/policies/higher-education/bologna-process-and-europeanhigher-education-area_en (accessed on 8 June 2020). 
19. Uhomoibhi, J.O. The Bologna Process, globalisation, and engineering education developments. Multicult. Educ. Technol. J. 2009, 3, 248-255. Available online: https://www.emerald.com/insight/content/doi/ 10.1108/17504970911004255/full/html (accessed on 8 June 2020). [CrossRef]

20. Société Européenne pour la Formation des Ingénieurs (SEFI). The Impact of the Bologna Declaration on Engineering Education in Europe-The Result of a Survey Among SEFI National Representatives and Other Members (As of June 15, 2004). Available online: http://sefibenvwh.cluster023.hosting.ovh.net/wp-content/ uploads/2017/08/Bologna-Declaration-Survey-Results-2001.pdf (accessed on 8 June 2020).

21. Bucciarelli, L.L.; Coyle, E.; McGrath, D. Engineering education in the US and the EU. In Engineering in Context; Christensen, S.H., Delahousse, B., Meganck, M., Eds.; Academica: Aarhus, Denmark, 2009; Available online: https://pdfs.semanticscholar.org/f3f5/57efdbb903b5d3f5a92e6af3704efd571484.pdf?_ga=2. 69537881.835784987.1587844731-776757956.1587844731 (accessed on 8 June 2020).

22. Engineering Education. Wikipedia. Posted 31 May 2020. Available online: https://en.wikipedia.org/wiki/ Engineering_education (accessed on 8 June 2020).

23. Davis, G.; O'Brien, L.; McLean, P. Growing in esteem: Positioning the university of Melbourne in the global knowledge economy. In The Tower and the Cloud: Higher Education in the Age of Cloud Computing; Katz, R.N., Ed.; Educause: Louisville, CA, USA, 2006; pp. 64-80. Available online: https://www.educause.edu/research-and-publications/books/tower-and-cloud/growingesteem-positioning-university-melbourne-global-knowledge-economy (accessed on 8 June 2020).

24. Longhairs and Short Waves; pp. 162-169, 206, 208; Longhairs vs. Hairy Ears, p. 115, Fortune, 1945, 32 , no. 5.

25. Kline, R. World war II: A watershed in electrical engineering education. IEEE Technol. Soc. Mag. 1994, 13, 17-23. [CrossRef]

26. History of the University of Michigan College of Engineering, 1940-1970. Available online: http://um2017. org/History_of_Engineering_1940-1970.html (accessed on 8 June 2020).

27. ABET. Criteria for Accrediting Engineering Programs, 2020-2021. Available online: https://www.abet.org/ accreditation/accreditation-criteria/criteria-for-accrediting-engineering-programs-2020-2021/ (accessed on 8 June 2020).

(C) 2020 by the author. Licensee MDPI, Basel, Switzerland. This article is an open access article distributed under the terms and conditions of the Creative Commons Attribution (CC BY) license (http://creativecommons.org/licenses/by/4.0/). 